УДК 621.793.72

\title{
ПРЕИМУЩЕСТВА И ОСОБЕННОСТИ ЭЛЕКТРОДУГОВОГО НАПЫЛЕНИЯ
}

\section{Борисова Мария Захаровна}

K.T.H., C.H.C.

ФГБУН ФИЦ «ЯНЦ СО РАН»

Институт физико-технических проблем Севера им. В.П. Ларионова СО РАН

Аннотация: В настоящей работе показаны преимущества и особенности электродугового напыления проволоки. Дуговое напыление проволокой является одним из наиболее экономически эффективных методов формирования износостойких покрытий. Эти покрытия характеризуются высокой прочностью, низкой пористостью, высокой производительностью процесса, изменчивостью состава напыляемого материала и хорошим уровнем износостойкости и сопротивления коррозии. Использование порошковой проволоки позволяет варьировать состав шихты в широком диапазоне.

Ключевые слова: электродуговое напыление, износостойкость, коррозионная стойкость, покрытие, адгезия, порошковая проволока.

\section{ADVANTAGES AND FEATURES OF ELECTRIC ARC WIRE SPRAYING OF THE MATERIAL}

\section{Borisova Maria}

\begin{abstract}
The present paper shows a advantages and features of electric arc wire spraying. Arc wire spraying is one of the most cost-effective methods for wearresistant coating formation. Those coatings are charachterized by high strength, low porosity, high process performance, variability of the composition of the sprayed material and a good level of wear and corrosion resistance. The use of powder wire allows you to vary the composition of the charge in a wide range.
\end{abstract}

Key words: electric arc spraying, wear-resistance, corrosion resistance, coating, adhesion, cored wire. 
Electric arc spraying as a recovery process is used from early in the 20th century (Schoop-Günther metallization process, 1917). It is one of the most multifunction techniques for the application of coatings used in protecting machines and details from wear, adhesion, erosion, corrosion, fatigue etc. Arc wire spraying is highly appropriate for protecting a wide coating surfaces due to the low cost and the availability of treatment [1-4].

Arc spraying is a technique where two wires made of electrically conductive materials are transported through a special wire guide. Between the ends of these wires an electric arc is resulting it to melt. The melted material is then transported due compressed air to the substrate (Fig.1).

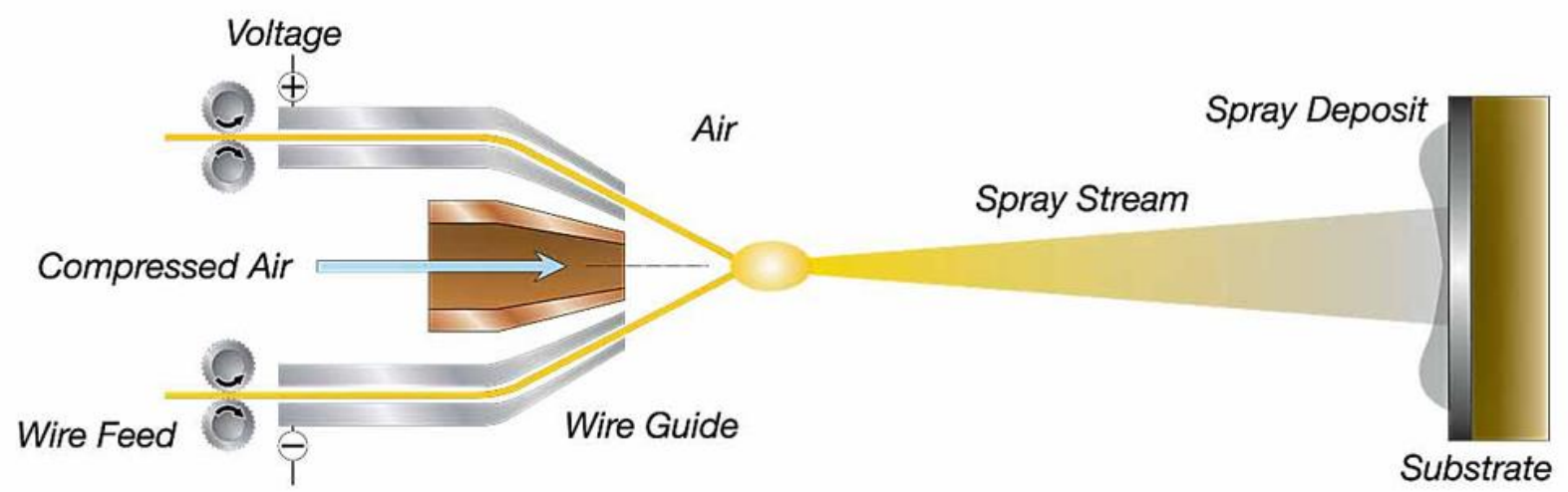

Fig.1. Scheme of the process of electric arc spraying.

The temperature the electric arc is of approximately $4000^{\circ} \mathrm{C}$ and provides a larger spray capacity and adherence. This technic allows a high quality coating to be applied inexpensive and in a short time. In addition to a wide spraying surface, this method can be used to obtain sufficiently thick layers (Fig.2).

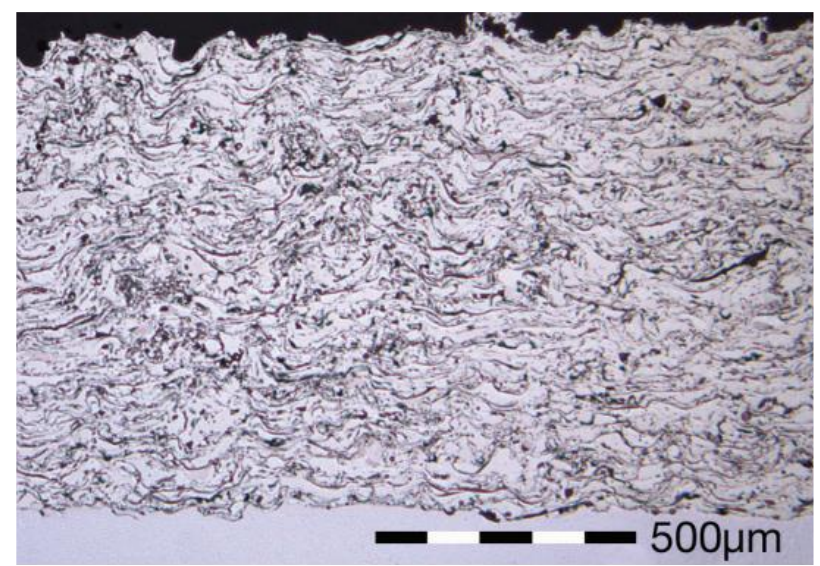

Fig. 2. Electric arc spray coating. 
Electric arc thermal spraying allows to applying corrosion and wear resistant coatings with high-quality adhesion and wide range of chemical composition. Moreover, the parameters used by the electric arc spraying, such as voltage, current, air pressure and spraying distance can be optimized for each special application.

At electric arc spraying, it can be observed intensive oxidation of the sprayed metal due to oxygen of the air. It can lead to a significant decrease of the alloyed elements content in the coating. In this way the quality of the sprayed layer is reduced. Use of a pulsating air spraying flow at the application of coatings by arc metallization can reduce the burnout of alloying elements in the applied coating. Pulsating air spraying method allows reducing of the consumption of spraying air and the quantity of burnout of alloying elements due to a decrease in the amount of oxygen contacting with sprayed metal drops.

The influence of compressed air pressure, with an increase in pressure, the quality of coatings improves, since with greater pressure, the size of the sprayed particles decreases. Thus, coatings with a more dispersed structure are obtained [5].

With arc spraying, the beam has an angle from 15 to 20 degrees. The smaller the distance to the substrate, the higher the density of the sprayed material, which leads to a decrease in the rate of their crystallization and an increase in size.

When arc metallization of powder wires with a diameter of $1.8 \mathrm{~mm}$, a current of $150 \mathrm{~A}$ to $300 \mathrm{~A}$ is used. The higher the current strength, the denser the coating with a more heterogeneous structure is obtained (Fig.3). But the use of an increased current value can lead to overheating of the part and contribute to excessive oxidation and peeling of the sprayed coating.

a)

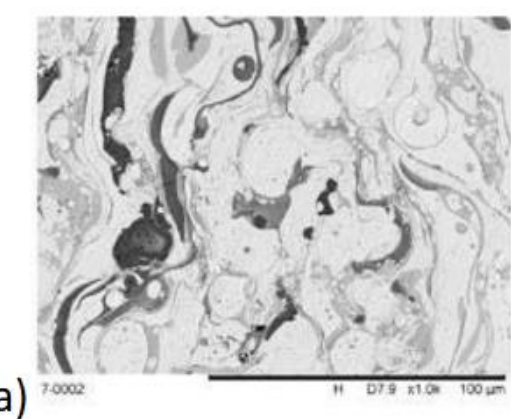

b)

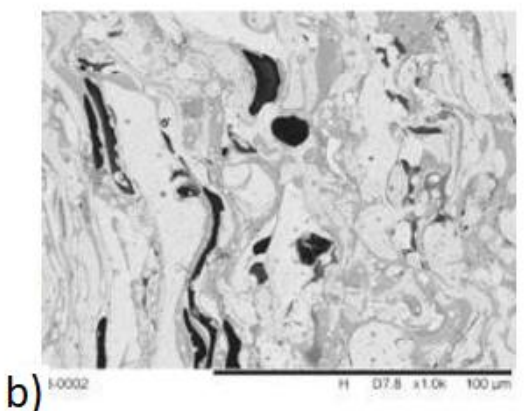

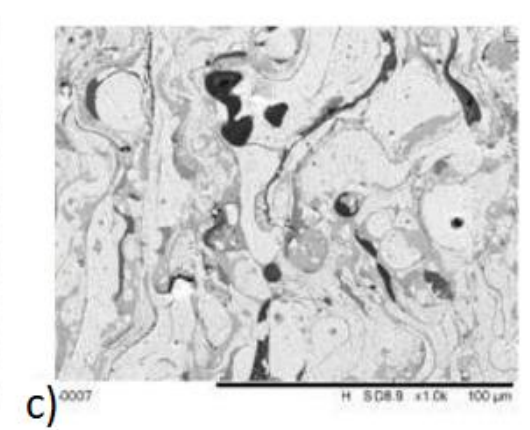

Fig. 3. Microstructure of the cored wires coatings obtained at different current strength.

Various cored wires are used as materials for the formation of coatings for wear- and corrosion resistant coatings [6]. Powder wires are a low-carbon steel strip 
with powder filling. Powders usually consist of ferroalloys, metals, nitrides or carbides. To obtain oxides with increased strength $\mathrm{Al}_{2} \mathrm{O}_{3}$ and $\mathrm{Cr}_{2} \mathrm{O}_{3}$, aluminum powder and ferrochromium are added [7]. In addition, you can change the composition of the casing and use a chromium steel coating instead of low-carbon steel, which contributes to obtaining a high-quality wear-resistant coating.

Therefore, by changing the parameters of electric arc spraying and the composition of the powder wire, it is possible to obtain coatings with the specified properties.

\section{References}

1. Wilden, J., Jahn, S., Reich, S. Production of high quality anti-corrosion and wear-resistant wire arc sprayed coatings. In Thermal Spray 2008: Thermal Spray Crossing the Borders on CD-ROM; Lugscheider, E., Ed.; DVS-German Welding Society: Maastricht, The Netherlands, -2008 .

2. Korobov, Y. Efficiency of using activated arc metallization for the deposition of protective coatings//Weld. Int. - 2005. - pp. 580-582.

3. Wielage, B.; Pokhmurska, H.; Student, M.; Gvozdeckii, V.; Stupnyckyj, B.; Pokhmurskii, V. Iron-based coatings arc-sprayed with cored wires for applications at elevated temperatures//Surface Coat. Technol. - 2013. - pp. 27-35.

4. Korobov Yu. S., Nevezhin S. V., Filippov M. A., Makarov A. V., Malygina I. Yu., Fantozzi D., Milanti A., Koivuluoto H., Vuoristo P. Properties of arc-sprayed coatings from Fe-based cored wires for high-temperature applications//AIP Conference Proceedings 1915, - 2017. - 020004.

5. Zhang, L. Su, S., Wang J., Chen S.J. Investigation of arc behaviour and metal transfer in cross arc welding. Journal of Manufacturing Processes 37, - 2019. pp. 124-129.

6. He D., Jiang J. Effect of Rare Earth Elements on the Wear Resistance of Iron-Based Thermal Sprayed Coatings//In Proceedings of the Thermal Spray 2004: Advances in Technology and Application, Osaka, Japan, 10-12 May, - 2004. pp. 61-64.

7. Borisova M.Z., Struchkov N.F., Vinokurov G.G. Evaluation of the content of corundum in the wear-resistant coating applied by wire arc metallization of a powder wire with fireproof additives//Procedia Structural Integrity, Volume 20, 2019. - pp. 48-52.

(C) М.3. Борисова, 2021 